\title{
Tájváltozások társadalmi hátterének vizsgálata alföldi példákon
}

\section{Social driving factors of landscape changes in the Great Hungarian Plain}

\section{KOVÁCS ANDRÁS DONÁT, FARKAS JENŐ ZSOLT}

KoVÁcS András Donát: tudományos munkatárs, Közgazdaság- és Regionális Tudományi Kutatóközpont, Regionális Kutatások Intézete; 6000 Kecskemét, Rákóczi út 3.; kovacsa@rkk.hu; https://orcid.org/0000-0002-7748-5945

FARKAS Jenő Zsolt: tudományos munkatárs, Közgazdaság- és Regionális Tudományi Kutatóközpont, Regionális Kutatások Intézete; 6000 Kecskemét, Rákóczi út 3.; farkasj@rkk.hu; https://orcid.org/0000-0002-4245-2908

KULCSSZAVAK: tájhasználati változások; tájtermelés; környezeti paradigma; természetvédelem - agrárium viszonya

ABSZTRAKT: Társadalmi életünk összetett mechanizmusok révén jelentős hatást gyakorol a tájakra. Úgy véljük, hogy ezen komplex földrajzi területi egységek állapotában az állami elképzelések, fejlesztési irányelvek, az intézményesült struktúrák, valamint a közösségi és egyéni érdekek és cselekvések is egyaránt megnyilvánulnak. Feltevésünk szerint a kultúrtájakban nyomon követhető események jól tükrözik az adott társadalom környezethez való viszonyát, így a tájak használatával összefüggo” folyamatok, avagy a „tájtermelés” az „új környezeti paradigma” egyfajta indikátorának tekinthető. E folyamatok alaposabb megértéséhez - kritikai, strukturalista megközelítésekre, kvalitatív és kvantitatív, térinformatikai elemzésekre támaszkodva - a földhasználati módokban bekövetkezett változásokat és az ezek mögött rejlő társadalmi hajtóerőket vizsgáljuk meg. Az elmúlt fél évszázadra vonatkozóan megpróbáljuk érzékeltetni, hogy a tájgazdálkodásban jelentős szerepet játszó természetvédelem és a mezőgazdaság miként alakította a hazai, alföldi térségek jellegét, ehhez kapcsolódóan pedig melyek voltak az egyes korszakok meghatározó mozzanatai. Továbbá feltárjuk, hogy hogyan értékelik az említett ágazatok szereplői az ökológiai szempontokat és az agrárium jelentőségét, valamint az ezeket befolyásoló beavatkozásokat. Duna-Tisza közi mintaterületeinken - a természetvédelem által eltérő mértékben érintett kunsági, illetve bácskai példákon - bemutatjuk azt is, hogy milyen konfliktusok keletkeznek és milyen dilemmák feloldása lesz szükséges a természetközeli állapotok megőrzése és az ezzel gyakran ellentétesen ható mezőgazdálkodás között. Végül az eredmények alapján megállapítjuk, hogy az új paradigma megerősödését eltérő társadalmi érdekek akadályozzák. A környezettudatos elvek ugyan megjelentek, de a tájgazdálkodásban átfogó előrelépés, illetve a tájak állapotában javulás az elmúlt évtizedekben összességében nem történt.

András Donát KOVÁCS: research fellow, Institute for Regional Studies Centre for Economic and Regional Studies; Rákóczi út 3., H-6000 Kecskemét, Hungary, kovacsa@rkk.hu; https:// orcid.org/0000-0002-7748-5945

Jenő Zsolt FARKAS: research fellow, Institute for Regional Studies, Centre for Economic and Regional Studies; Rákóczi út 3., H-6000 Kecskemét, Hungary, farkasj@rkk.hu; https://orcid.org/0000-0002-4245-2908

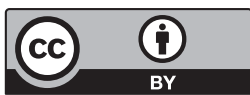


KEYWORDS: land use change; production of landscape; environmental paradigm; relations of nature conservation and agriculture

ABSTRACT: Our social life has a significant impact on landscapes through complex mechanisms. The authors believe that governmental ideas, development policies, institutionalised structures, and our interests and activities manifest themselves in various units. Cultural landscapes reflect society's relationship with the environment. Thus, the processes related to the use of landscapes, i.e. "landscape production", can be seen as indicators of the "new environmental paradigm". (The new environmental paradigm represents a "worldview" and an era in which nature conservation and environmental protection become the ultimate goal.)

To better understand these processes - based on critical, structuralist approaches, qualitative and quantitative GIS analyses - we focus on land use conversions and the social driving forces and responses behind land use patterns. We try to show how nature conservation and agriculture have played a major role in landscape management, shaping the character of the Hungarian lowland regions, and to identify what have been the decisive moments of each epoch in the last 50 years.

In addition, we examine how the actors in these sectors value the ecological aspects and the importance of agriculture, as well as the interventions affecting them. Using the examples of the areas of Kunság and Bácska (differently influenced by nature conservation), we also want to investigate the conflicts and dilemmas of nature conservation and agriculture in the Danube-Tisza interfluve.

The results show that efforts to strengthen the new paradigm are hampered by different social interests. Although environmental principles have emerged, there has been no comprehensive improvement in landscape management or landscape condition in recent decades. Based on the historical events studied using primary data and statistical analyses, it can be seen that the attitudes of society and the conflicting needs of land use play a crucial role in land use change and landscape production.

The new directions of ecological thinking and some elements of the new environmental paradigm appeared in the last five decades. These directions manifested themselves in the segments influencing land use, i.e. in both agriculture and nature conservation. It is also striking that ecological principles have been integrated late and inefficiently into decision-making mechanisms, landscape development practices and rural planning.

The agro-environmental and NATURA2000 schemes have facilitated cooperation between nature conservation and agriculture, but are based on subsidies rather than on producer awareness. Our views are in line with our respondents' comments that sustainable nature conservation should not be subordinated to economic objectives, but at the same time, national parks must also accept the rationalisation of farming practices.

\section{Bevezetés és célkitűzés}

Kutatásunk ${ }^{1}$ elméleti kiindulópontját azok a kritikai-strukturalista megközelítések adják, amelyek a térre alapvetően úgy tekintenek, mint társadalmi interakciók leképeződésére, ahol az adott geográfiai körülmények között sajátos „helyi entitások" képződnek (Giddens 1984; Hillier, Hanson 1984; Lefebvre 1991; Massey 1991; Soja 1989). A tájakkal, mint önálló térbeli egységekkel kapcsolatosan ma már általánosan elfogadott megállapítás, hogy jelenkori alakításukban az emberi közösségeknek döntő szerepe van (Kauffman, Levin 1987; Konkoly-Gyuró et al. 2017; Sargolini 2013). Fazio és Modica (2018) megfogalmazásában a tájakat ma már nem is lehet másként értelmezni, mintsem természeti-ökológiai, valamint 
historikus és kulturális evolúciójuk alapján. A kérdés sok esetben az, hogy vajon a természetes alapstruktúrákat az antropogén hatások mennyire változtatták meg végérvényesen és mennyire dominálnak a mesterségesen létrehozott állapotok (Fazio, Modica 2018). A mindenkori társadalom berendezkedése mindenesetre a tájváltozások tekintetében kulcsfontosságú tényező. Egyetértünk tehát azokkal a szerzőkkel, akik szerint a nemzetállamok stratégiai elvei, a területi tervezést érintő kormányzati megfontolások, az intézményi rendszerek irányítási mechanizmusai, valamint az adott társadalmi közösségek felfogása a táji folyamatokban is nyomon követhetö (Antrop 1997; Ellis 2011; Foley et al. 2005; Muir 1998; Renes 2015; Solymosi 2011).

Gondolatmenetünk másik alapvetően fontos eleme az „új környezeti paradigma" nézőpontjának használata, amely alatt a 20. század második felében kibontakozó környezettudatos vezérelvek, értékek és cselekvési minták összességét értjük. ${ }^{2} \mathrm{~A}$ fenntarthatóságra való törekvés, avagy ennek ellentéteként annak elodázása és figyelmen kívül hagyása - meglátásunk szerint - az antropogén behatásra módosuló földfelszínen is tetten érhető. Vagyis az új paradigma meglététől, elmélyültségétől függő tevékenységek egy része a táji rendszerek jellegében és végeredményben azok fenntarthatóságában is megmutatkozik. Ebben a kontextusban az ökológiai szempontú természetmegóvás és a mezőgazdálkodás egymásra hatásából adódó változások az új környezeti paradigma, valamint a környezettudatosság fokmérői lehetnek (Cosgrove 1997; Yu, Verburg, Wu 2018).

Elvi kiindulópontjainkra építve, kutatásunk célja a tájhasználatban bekövetkezett jól kivehető változások bemutatása és az ezeket befolyásoló, egyes társadalmi elgondolások és beavatkozások jellemzése egészen a rendszerváltást megelőző évtizedektől napjainkig. Munkánkban az Alföldre és annak két olyan mikrorégiójára koncentrálunk, ahol a tájgazdálkodás kérdései mögött az esetek többségében a természetvédelem és az agrárium „párharca” válik láthatóvá. Két mintaterületünkön - a Kiskunsági Nemzeti Parkhoz tartozó, illetve a parkhoz közel eső Felső-Kiskunságban, valamint a Bácskai löszhát térségében - a földhasználatban észlelhető váltásokra, és az ezek mögött fellehető hajtóerőkre, illetve bizonyos intézményi és egyéni válaszreakciók feltárására és megértésére koncentráltunk.

A hazai és alföldi táji változások tendenciáit bemutató szakirodalom és saját tapasztalataink alapján alapvetésnek tekintjük, hogy az érintett kultúrtájak ma sokkal inkább a társadalmi igényeknek megfelelően átalakított struktúrákat mutatják, mint az eredeti karakterüket (Andrásfalvy, Vargyas 2009; Bíró 2011; Büttner 2010; Csorba, Csatári 2017; Duray, Keveiné 2010; Kerényi 2006; Kovács 2011; Kulcsár 2014; Szilassi 2015, 2017). Éppen ezért úgy gondoljuk, hogy - az új környezeti paradigma megerősödése kapcsán - a területhasználatban megjelenő érdekellentétek és helyi konfliktusok további értelmezése, valamint a fenntartható tájgazdálkodásra ${ }^{3}$ vonatkozó javaslatok megfogalmazása fontos és sürgető feladat. 


\section{Elméleti kiindulópontok - az ember és a táj kapcsolatának kérdése}

„A táj a vizuális képzelet és az anyagi világ együttes megjelenésére vonatkozó legtalálóbb kifejezés", ugyanakkor mindannyiunk számára mást jelenthet, hiszen képzeletünk egyéni percepciókból fakad (Cosgrove 2003 idézi Minca 2013, 55.). Ez a meglátás egyrészt a tájképről való absztrakcióink eltérőségére utal, ugyanakkor rámutat, hogy a szubjektivitás mellett mindvégig központi kérdés marad a táj és az ember kapcsolatrendszere (Cosgrove 1984; Wang, Liu, Chen 2013; Wylie 2007). Egyes szerzők (kutatási nézőpontoktól függetlenül) következetesen kiemelik, hogy a kultúrtájak létrehozása során (kvázi a „tájtermelésben”) legfoképpen azok a társadalmi tényezők érvényesülnek, amelyek egyébként is meghatározzák a közösségek értékrendjét, életformáit, szokásait (Boucher et al. 2014; Rössler 2006; Widgren 2012). A tájak kulturális identitásunk földrajzi keretét adják, ott van bennük az ember, ,az előző nemzedékek munkája, ott van a történetiség” (Csemez, Salamin 2006, 7.), és ezzel együtt az adott közösségek természettel való kapcsolatát, életmódját is jól mutatják (Csorba 2010; Kerényi 2007). Ebből következik, hogy a körülöttünk lévő földfelszín mai arculatát leginkább az uralkodó tudományos paradigmákon, viselkedési formákon, attitüdökön keresztül lehet megérteni (Swanwick 2009). Vagyis a táj, (amennyiben azt dominánsan társadalmilag konstruált térként vesszük szemügyre) karakterében és változásaiban mutatja meg a benne élők szellemiségét, bizonyos értelemben az adott emberi közösség civilizációs fokát (Görg 2007; Greider, Garkovich 1994). Sőt, mint „egyedi térbeli minőség" az államnak és az egyéneknek a környezethez való viszonyát is tükrözi (Calvo-Iglesias et al. 2009; Kőszegi et al. 2015; Plieninger et al. 2006). Gailing és Leibenath (2015) úgy fogalmaz, hogy a geomorfológiai értelemben vett megjelenés és a fizikai, földrajzi valóság folytonos átalakulása mögött jól tipizálható struktúrákat, szemlélet- és életmódokat lehet beazonosítani. A felszínen zajló folyamatok ismeretében jobban érthetővé válnak egyes korszakok (melyek lehetnek akár kormányzati ciklusok is), bizonyos trendek, központi irányítási és működtetési módszerek is (Gailing 2012; Wöbse 2002).

Vannak, akik hozzáteszik ehhez, hogy a jelenlegi földhasználati változások az adott vidéki térségek, tájegységek átalakulásának markáns indikátorai (Cloke 2000; Marsden 1998; Newby 1985). ${ }^{4}$ Halfacree (2006) a Lefebvre- (1991) és Whatmore(1993) féle konceptuális térbeli elméleti kereteket is „beemeli” a gondolatmenetébe, és azt vallja, hogy a táj nemcsak létezik, passzívan várva, hogy felfedezzék, feltérképezzék és kiaknázzák, hanem sokkal inkább folytonosan és dinamikusan változó, összetett és autonóm térrendszert képez. A kultúrtájak tehát az emberi igényeknek megfelelően alakított, tudatos cselekvési sorozatok által formálódó, társadalom által megtermelt térnek tekinthetők (Csorba 2000; Frisnyák 2001; Marosi 1981; Taylor, Lennon 2011; Thrift 1999). Például ilyen tereket képeznek hazánkban a folyószabályozások nyomán kialakult szántóföldek, a homokhátsági erdők, vagy a lakóhelyi, üdülési-pihenési funkiók bővülésével átlakult mezővárosi tanyás külterületek. 
Buckwell és társai (2017) a tájakkal szemben támasztott eltérő társadalmi igények kapcsán több felszínformáló tényezőre és konfliktusra is rámutatnak. Többek közt megemlítik, hogy a központi, állami prioritások, illetve a valós helyi érdekek között jelentős eltérések lehetnek. Ez gyakran kedvezőtlen jelenségekhez vezet: romboló beruházásokhoz, pazarló intézkedésekhez, vagy éppen a környezetbiztonság figyelemen kívül hagyásához. Az Európai Unió tagállamaiban a tájak revitalizációjára költött források emelkedtek ugyan, de az eddig okozott károk helyrehozatalára nincs mindenütt lehetőség. A különböző mintázatú tájtípusok által nyújtott előnyökben is egyfajta térségi-társadalmi versenyhelyzet alakult ki, amely tovább fokozza a vidéki térségek differenciálódását, leszakadását. Az is érzékelheto", hogy a tájak sokoldalú használatával megteremthető dinamikus környezeti egyensúlyi helyzet nemcsak nagyon törékeny, de a lehetőségekhez és elvárásokhoz képest kevés olyan hatékony művelési alternatíva terjedt el, amely környezettudatos, lokális sajátosságokra építő tájhasználat-menedzsmentet biztosítana. A tájak fenntartása, megőrzése tehát továbbra is komoly kihívást jelentenek, mind a természetvédelem, az agrárium, mind a vidékfejlesztés számára (Buckwell et al. 2017).

\section{Alkalmazott módszerek}

\section{A vizsgálati terület}

A tájhasználati változások hátterében álló bizonyos társadalmi hajtóerők megvilágítására és a „tájtermeléssel” összefüggo, vidéki állapotokat befolyásoló szektoriális ellentétek megértéséhez az országos szintű áttekintés mellett egy regionális és két kisebb térségi, alapvetően kistájakra szabott vizsgálatot végeztünk el. Korábbi eredményeink azt mutatták, hogy hazánkban a legintenzívebb felszínborítási változások a rendszerváltás után a Duna-Tisza közén, valamint a Nyírségben zajlottak le, így célszerủ volt az Alföld nagytáját kiválasztani, mint regionális keretet (Farkas, Kovács 2017; Kovács, Farkas, Hoyk 2017). Kisebb léptékben pedig olyan konfliktusokkal terhelt „övezeteket” kerestünk, melyben a mezőgazdasági termelés és a földhasználat, valamint a természetvédelem érdekütközése szembeötlő. E szempontoknak a Felső-Kiskunság felelt meg legjobban. Itt egyedi helyzetet teremtett az 1970-es évek végétől működő, markáns tájvédelmi érdekeket képviselő Kiskunsági Nemzeti Park (KNP), ugyanakkor a mezőgazdasági ágazatok jelenléte is mindig erős volt. A táj használata mozaikos, környezeti szempontból pedig igen érzékeny a térség, a szárazodás jelentős kihívást jelent.

A Felső-Kiskunság mellett egy olyan kistájat igyekeztünk kiválasztani, ahol a természetvédelem pozíciói kevésbé erősek, és az egykori államszocialista rendszerben kialakított iparszerü, nagytáblás művelés - a tulajdonviszonyok átalakulása ellenére - továbbra is fennmaradt. Ilyen terület több is van az Alföldön 
(pl. Békés megye, Nagykunság, Hajdúság), de a Duna-Tisza köze komplex áttekinthetősége okán Bácska mellett döntöttünk.

\section{Módszerek és felhasznált adatbázisok}

A kutatás során primer és szekunder adatokat egyaránt felhasználtunk, és azok feldolgozását kvantitatív és kvalitatív metódusok együttes alkalmazásával végeztük el. Az elsődleges adatgyűjtés elején a Felső-Kiskunságra és Bácska térségére vonatkozóan 30-30 strukturált mélyinterjút készítettünk el különböző szakemberekkel, prominens személyekkel. Egyes kérdezettek nem feltétlenül éltek az adott térségben, de életútjuk során rálátásuk volt mindkét térségre, mint például Rakonczay Zoltán, a magyar természetvédelem legendás alakja esetében. A válaszadók megbízható és sokoldalú kompetenciáját mutatja, hogy volt köztük nyugalmazott miniszter-helyettes, ex-államtitkár, intézményvezető, helyi döntéshozó, országosan ismert nagyvállalkozó, valamint agrár- természetvédelmi, környezetvédelmi, erdészeti, vízügyi szakember, gazdálkodó és őstermelő egyaránt. Az interjúalanyok vezetésével gyakran sor került terepbejárásokra, az elmondottakat pedig az általuk hozzáférhetővé tett, adott témához kapcsolódó dokumentumok elemzésével is kiegészítettük.

A kvalitatív tartalomelemzés során kapott eredmények alapján, második lépésben egy survey-jellegü kérdöívezésre is sor került, melyben véletlenszerü kiválasztással, random walk metódussal, 654 fö válaszait rögzítettük 4 településen. Ezek közül Kunszentmiklós esett a szűkebb kutatási területünkre (Felső-Kiskunság), és további kettő (Hortobágy és Mezőhegyes) az Alföldre. ${ }^{5}$ A kérdőíves felmérés nem tekinthető reprezentatívnak, de a minta nagysága feldolgozható elemszámot biztosít. Az adatokat Excel és SPSS segítségével rendszereztük és elemeztük.

A szekunder adatforrások közül a felszínborítási adatokat tartalmazó Corine Land Covert (1990 és 2018), valamint a változásokat összesítő Corine Land Cover Change-et (1990-2000, 2000-2006, 2006-2012 és 2012-2018) kell kiemelnünk, melyeket a Copernicus Land Monitoring Service oldaláról értük el. A védett és a Natura 2000 területek 2017-es referenciaévre vonatkozó térinformatikai adatállományát és az elmúlt 25 év kontinentális változásait mutató jelentést (EEA Report 2017) az Európai Környezetvédelmi Ügynökség honlapjáról töltöttük le. A felszínborítás-változások elemzéséhez felhasználtuk a KSH INSPIRE projektben elkészült $5 \times 5 \mathrm{~km}$-es referencia rácsot, melynek elemeire ArcGIS és Excel segítségével összesítettük a CLC Change adatbázisokban rögzített felszínborítás-változások adatait. 


\section{Az empirikus kutatások eredményei}

\section{A mezőgazdaság és a természetvédelem viszonyának változásai - interjúk és kérdőivek tapasztalatainak tükrében}

Vizsgálataink során a megkérdezettek széles körü tudására, az interjúalanyok tapasztalataira támaszkodva olyan releváns és részletgazdag információkat kaptunk, amelyek egyértelmü következtetésekre, objektív megállapításokra adnak lehetőséget. Interjúalanyaink megerősítették elvi kiindulópontunkat és a hazai tájakkal kapcsolatos előzetes felvetéseinket; vagyis a történelmi események, szakpolitikai célok és irányváltások, intézményi átstrukturálódások olyan társadalmi, gazdasági változásokat, konkrét cselekményeket is előidéztek, amelyek az alföldi tájak környezeti viszonyaira és tájképére is jelentős hatással voltak. A rendszerváltást megelőző, majd az azt követő ágazati koncepcióváltások, az EU-csatlakozás után megjelenő ágazati szakpolitikák az elmúlt fél évszázadot különböző periódusokra tagolják. Az elmondottak és a kapcsolódó dokumentumok elemzése alapján a vizsgált időszakra vonatkozóan a földhasználatra ható, mezőgazdasággal és természetvédelemmel összefüggő legfontosabbnak ítélt eseményeket, fordulópontokat az alábbi idővonalon foglaltuk össze (1. ábra).

Az elmúlt fél évszázad tájhasználati változásai mögött a legtöbben a két legnagyobb „földhasználó szektor párharcát”, és az e mögött rejlő állami intézkedéseket és beavatkozásokat vélték a legfontosabbnak. „A földhasználatra a mindenkori kormányzás és a makrogazdasági körülmények gyakorolják a legnagyobb nyomást. A gazdálkodók többsége igyekszik alkalmazkodni a szabályozásokhoz, de anyagi érdekeltségektől, szemlélettöl függően nagy különbségek vannak a földhasználatban, a szükebb táji környezet gondozásában" - mondta ezzel kapcsolatban egy szakember.

A kiskunsági mintaterületen évtizedeken át nagy jelentőséget kapott a természetvédelem. Erősödő poziciójában már az 1970-es évektől szerepet játszott az élőhelyek és kulturális értékek védelmének favorizálása és néhány karizmatikus (országos és helyi) vezető elhivatottsága. Itt a védett földterületek jelentős része fokozatosan állami tulajdonba került, amelyeket aztán a nemzeti park kezelésébe adtak át. 1975-ben a Kiskunsági Nemzeti Parkban a védett területek 37\%-a volt parki kezelésben (és állami tulajdonban), míg 2003-ban ez az arány több mint 50\%-ra növekedett (41 395 hektár a 76000 hektáros összterületből). A védelem alá vont földterületek kapcsán az érdekeltek között ellentétek alakultak ki: amíg a természetvédelem egyre nagyobb müvelhető területre terjesztette ki hatókörét (hatósági jogkörét), a TSZ-ek is igyekeztek birtokaikat növelni, pl. a szántóterületeiket a gyepek és a szikes tavak kárára. A vitáknak voltak enyhébb és drasztikusabb (perek) megnyilvánulásai, de végül a szembenállók többnyire belátták, hogy közös érdekről van szó; - a kiskunsági táj hosszú távú megőrzéséről. „A megegyezést elösegitette az is, hogy a szocializmusban is léteztek magángazdálkodók, még ha kis számban is. A gazdálkodók földterületei beékelődve helyezkedtek el a szövetkezeti vagyon- 

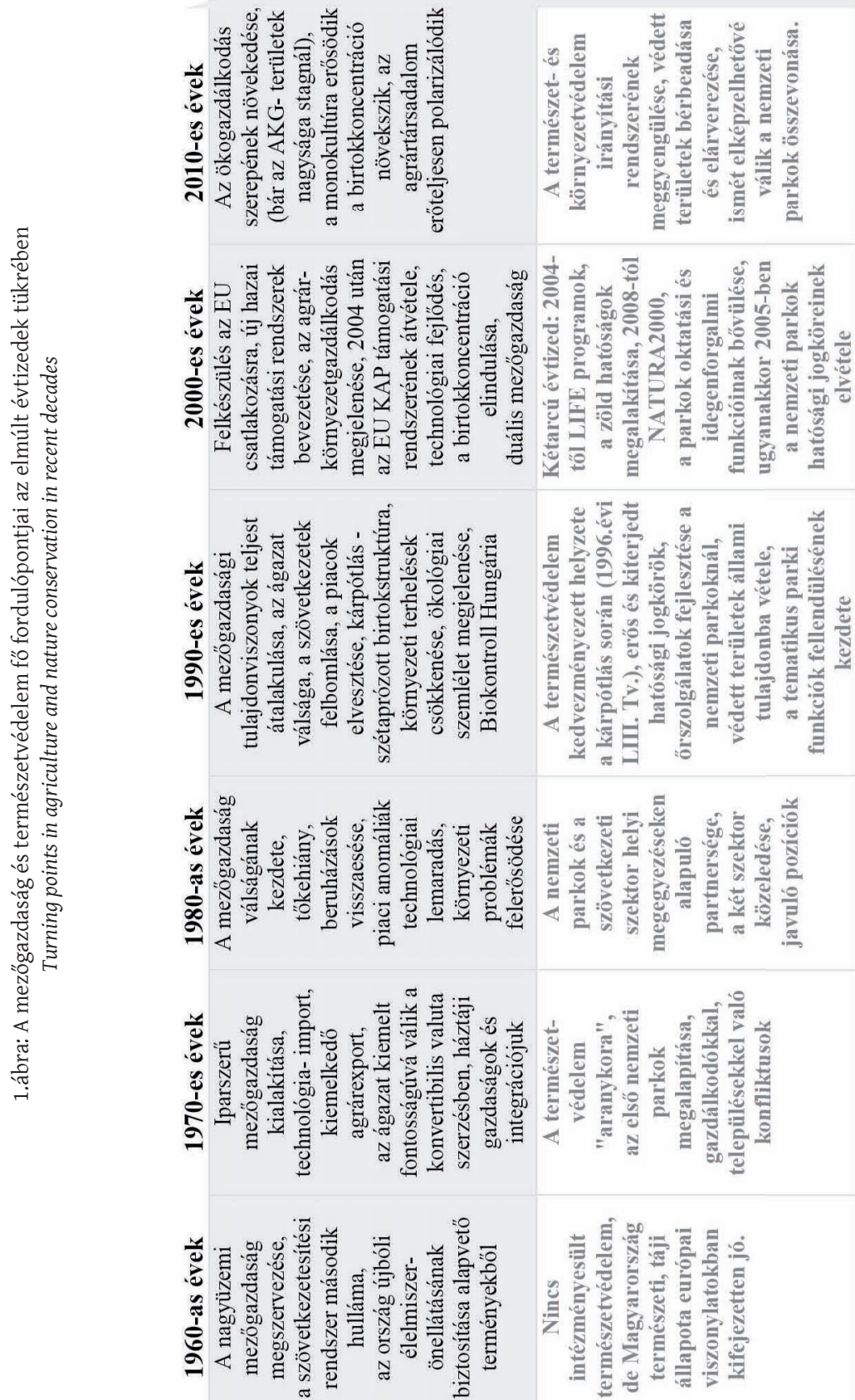
ban. Ez a helyzet a Kiskunság egyes térségeiben háttérbe szorította az alkalmazott nagyüzemi technológiákat (pl. helikopteres növényvédelem), ezzel kedvezve a természetvédelemnek" - világított rá egy korábbi nemzeti parki vezető.

A rendszerváltást követő privatizációval azonban ismét felerősödtek a konfliktusok, a visszaélések és az abból fakadó területfelhagyások, amelyek alapvetően a táji állapotromlás irányába hatottak. Az alapvető problémát az jelentette, hogy a nemzeti park területei nem voltak pontosan nyilvántartva (ekkor nem létezett a területekről pontos helyrajziszám-kataszter). Így a kárpótlás során létrehozott földalapokba (pl. a nemzeti park külön alapjába) nem lehetett egyértelmủen besorolni az egyes táblákat, illetve a KNP olyan parcellákra is igény tartott, amelyeket korábban a TSZ kezelt, de szerették volna a természetvédelem számára megszerezni. Ezek a nézeteltérések később rendeződtek, elsősorban annak köszönhetően, hogy az állam forrásokat biztosított a KNP-nek a földvásárlásra. Ezért is nőtt jelentősen az állami tulajdon aránya a területből. Az 1990-es évek folyamán ezt a törekvést a Felső-Kiskunságban magáncégek is támogatták pl. a GlaxoSmithKline Magyarország gyógyszeripari cég, vagy a Magyar Telekom. A nemzeti park az 1990-es évek első felében nem volt felkészülve a megnövekedett terület - különösen a szántók - kezelésére, így azokat a megmaradt TSZ-eknek haszonbérbe adták. (Kölcsönös volt az egymásra utaltság, hiszen a szövetkezetek éppen elvesztették a földjeiket). A szerződésben pontosan szabályozták a termelés feltételeit, így ez az időszak volt az első alkalom, hogy napi szinten is bele tudtak szólni a termelési folyamatba.

Ezt követően az agrár-környezetgazdálkodás rendszere (2003-ban még nemzeti, de egy évvel később már uniós forrásból) hozott nyugodtabb időszakot a gazdálkodók és a KNP között. A park tájgazdálkodásban betöltött szerepe és funkcióbővülése egészen a kétezres évek közepéig töretlen volt. „Úgy tünt, hogy számos probléma rendezödött, és az érdekelt szereplök (térségektöl is függöen) több kérdésben kiegyeztek.” "Voltak visszatérően jelentkező konfliktusok, de ezek egy része a felek konszenzusával megoldódott." - füzte hozzá egy gazdálkodó.

A jelenlegi állásfoglalások (amelyek a természetvédelmi szakma felől értelemszerüen élesebben fogalmazódnak meg) egy kiegyensúlyozatlan állapotra, a természetvédelem csökkenő erejére hívják fel a figyelemet. „A visszaszorulás 2005 óta tart; az intézményrendszert érintô állami intézkedésekkel az agrárium és a természetvédelem pozíciói ismét kiegyenlitetlenek lettek, az elóbbi javára”. „Ráadásul az agrártámogatások maximalizált lehívása, és a nemzeti parkok által kezelt területek Nemzeti Földalapkezelő Szervezethez való átkerülése a végletekig kiélezi a tájhasználati érdekellentéteket, amin az AKG-rendszer nem képes segíteni". Így aztán az ökológiai szempontok mellett érvelők egyre kevésbé tudják a gyakorlatban is érvényesíteni elképzeléseiket, egyre inkább érzékelhetővé vált, hogy az állam és az önkormányzatok nem értékelik megfelelő súllyal a környezeti értékek megőrzésének szerepét. Aggodalmaikat egy kerekasztal-beszélgetés résztvevői így foglalták össze: 
„A természetvédelem és a gazdálkodás viszonyrendszerére nagyban ható nemzeti parki igazgatóság és az ökologikus szemlélet alapvetöen a fenntarthatóság irányába terelte a tájak használatát, ugyanakkor ellentmondásos társadalmi reakciókat is kiváltott. 2005-tól jelentösen megváltozott a helyzet; a parki hatósági jogkörök elvesztésével a természetvédelem komoly presztizsveszteséget szenvedett el a térségben, és ezt a Natura 2000 hálózat kialakításával járó körülmények sem tudták helyrebillenteni. Sőt! Sokan nem tudták megérteni a célokat, ami azt eredményezte, hogy a természetvédelem megitélése inkább romlott!"

Természetesen nemcsak ez képezte a negatív megítélés alapját, hanem több interjúalanyunk véleménye szerint az is, hogy korábban az igazgatóság a hatósági (pl. építéshatósági) jogköreinek alkalmazásakor csak saját ágazati érdekeit vette figyelembe indokolatlan korlátozásokat, tiltásokat eloírva (e hibákat a már említett kerekasztal-beszélgetésben a KNP kollégái is elismerték).

A bácskai térséget a korábbiakban ismertetett folyamatok kevésbé érintették, hiszen ott a nagytáblás gazdálkodás túlsúlya mindvégig megmaradt. „A természetvédelem jelentősége a monokultúrákon sosem volt erős, de az ökológiai folyosók és élőhelyek egészen jó állapotban megmaradtak" - tette hozzá egy természetvédelmi szakember. A helyi válaszadók a társadalmi problémákat hangsúlyozták: „a vidéki élet elértéktelenedett, a térség mezőgazdasága nem fog többé megélhetést nyújtani”, ,egy-két mágnás jelenléte meghatározó, akik a profitra való törekvés mellett még igyekeznek felkarolni az itt élőket, de ettől eltekintve a TSZ-ek megszünése óta a helyi társadalom nem talált magára". A Duna menti erdős zónákban az erdőgazdálkodás-vadászat-természetvédelem oppozíciói miatt is felmerültek éles viták, s ezek táji kihatásairól a szakemberek véleménye ma is megoszlik. Egyesek „visszaadnák a természetnek az ártereket”, míg mások „, a végletekig kihasználnák a helyi környezeti adottságokat". Többen is elmondták, hogy az ágazatok közötti „feszültségeket” „a jelenlegi intézményrendszer struktúrája és funkcionális megosztása, a túlbürokratizált múködés” okozza. Ráadásul „hiányoznak azok a szakmai kerekasztalok, amelyek korábban egyensúlyban tartották az eltérő érdekeket. Így válhatott a fakitermelés „rablógazdálkodássá”, vagy a vadászat „profitorientált sporttá”. „Ezek a zavarok jól láthatók a tájban; például az erdők tekintetében is az ültetvényjelleg, a gazdasági haszonszerzés dominál".

Az interjúkat kiegészítő kérdőív a lakosság ismereteire fókuszált. A felmérés három lényegretörő kérdést tartalmazott, ami alapján kijelenthető, hogy a helyiek viszonylag nagy csoportjai nem rendelkeznek kellő információval ahhoz, hogy megítéljék a közelmúlt és a jelen tájgazdálkodási gyakorlatát. Egyes kérdésekre feltűnően magas arányban, 28\%-ban nem akartak, vagy nem tudtak válaszolni, ami véleményünk szerint arra is rámutat, hogy a vidéki lakosság mennyire bizonytalan a hazai agrártermelés környezeti hatásainak megítélését illetően. Ugyanakkor a válaszadók egy része pozitívan vélekedik közvetlen környezetének állapotáról: közel harmaduk úgy vélte, hogy a lakóhelyét övező tájak állapota javult, a mezőgazdasági tevékenységek a természeti adottságokhoz igazodtak, és a 
külterületek állapota jó. 30\%-uk úgy látja, hogy nem történt változás, illetve a mezőgazdasági tevékenységek a természeti adottságokhoz csak részben igazodtak, és csak 7\%-uk gondolta azt, hogy „a tájak állapota jelentősen romlott”. Némi tájékozatlanságot fedezhetünk fel egy másik kérdésben is, ahol a szakembereknek ellentmondóan, a válaszadók közel kétharmada nem látja problémának a természetvédelemi ágazat érdekérvényesítésének gyengülését. A „természetvédelem háttérbe szorulását" a kérdezettek 3,4 pontra értékelték egy 1-től 4-ig terjedő skálán, ahol az 1-es azt jelenti, hogy súlyos problémát jelent-, míg a 4-es, hogy egyáltalán nem jelent problémát. Vagyis a természetvédelemnek tájgazálkodásban betöltött szerepét a lakosság nem ismeri fel, ezzel mintegy elfogadva annak leépítését.

\section{A földhasználat átalakulása, statisztikai és térinformatikai elemzés}

Statisztikai és térinformatikai elemzéseinkkel szerettük volna bemutatni a földhasználatban nyomon követhető változásokat, mégpedig oly módon, hogy közben reflektálni próbálunk a kvalitatív elemzés eredményeire is. A makrofolyamatok érzékeltetéséhez elsőként a KSH vonatkozó hosszú idősoros adatait tekintettük át, melyek segítségével általános trendeket határoztunk meg 1962-től (a 2. szövetkezesítés konszolidálásától) 2017-ig. Azt tapasztaltuk, hogy a legnagyobb területeket elfoglaló művelési ágak egyirányú trendek mentén változtak az elmúlt évtizetedekben (2. ábra). 1962-től kezdődően a szántók és gyepek területe csökkent, míg az erdők és a művelés alól kivett területeké nőtt. A változások di-

2. ábra: A művelési ágak változása 1962-2017 között Magyarországon

Changes in land use categories between 1962-2017 in Hungary



Forrás: KSH adatai alapján a szerzók szerkesztése 
namikája 1990 után megnőtt, főként a beépített területek növekedése esetében. E kategória a rendszerváltozást megelőzően éves szinten 4550 ha-ral, míg 1990 után már 32000 ha-ral bővült, jól kifejezve azt, hogy az államszocialista berendezkedésről a szociális piacgazdaságra történő átállás jelentősen megváltoztatta a földhasználati módok iránti igényt, és ezzel a tájak arculatát.

A Corine Land Cover Change (CLC) adatai ezzel összhangban, de már területi bontásban mutatnak hasonló eredményeket. Az adatbázis szerint Magyarországon 1990 és 2018 között a felszínborítás-változások által érintett területek nagysága 1,15 millió ha. A változások 56\%-a az Alföldre, az ország legfontosabb mezőgazdasági területére esett, és 28 év alatt 646000 ha-t tett ki. Az 5×5 km-es referencia-hálózat egységeire számolt adatok alapján kapott felszínborítás-változási arányokról az 1. táblázat, míg ennek térbeliségéről a 3. ábra ad képet.

Az Alföldet tehát az országoshoz hasonló trendek jellemzik, a beépített és az erdők területének növekedésével, a szántóterületek csökkenésével. Ugyanakkor a nagytáj természeti jellegzetességeiből, valamint társadalmi, gazdasági folyamataiból következően a művelési ágak átalakulásának üteme lassabb.

Az 1. táblázat adatai mellett célszerü megvizsgálni a CLC Change 44 felszínborítási kategóriára vonatkozó adatait is, amelyek összesítése részletesebb információt szolgáltat a felszínborítási konverziók irányairól. Ez alapján az derül ki, hogy a Homokhátságon és a Nyírségben jelentős a különböző mezőgazdasági földhasználatok közötti váltás (pl. szőlő vagy rét/legelő szántófölddé alakítása). E kedvezőtlenebb adottságokkal rendelkező tájakon az agrárium jövedelemtermelő képessége mindig is alacsonyabb volt, és a rendszerváltás utáni kihívások; a tulajdonosi és üzemszerkezeti átalakulása, a piacvesztés tovább rontották helyzetét. Ebből következően az itteni termelők mind a piaci, mind az intézményi környezet átalakulásáira nagyon érzékenyen reagáltak, és akár 5-10 éves időtávlatban gon-

1. táblázat: A felszínborítás változása 1990 és 2018 között az Alföldön Changes in land cover between 1990-2018 in the Great Hungarian Plain

\begin{tabular}{lccc}
\hline \multicolumn{1}{c}{ Felszínborítás típusa } & $\begin{array}{c}\text { Területi arány, } 1990 \\
(\%)\end{array}$ & $\begin{array}{c}\text { Területi arány, 2018 } \\
(\%)\end{array}$ & $\begin{array}{c}\text { Változás } \\
(\%)\end{array}$ \\
\hline Települési területek & 5,5 & 6,4 & 0,9 \\
Szántóföldek & 62,4 & 59,5 & $-2,8$ \\
Szőlő & 1,2 & 0,8 & $-0,5$ \\
Gyümölcsös & 0,9 & 1,0 & 0,1 \\
Rét/legelő & 8,2 & 8,3 & 0,1 \\
Egyéb mezőgazdasági területek & 5,0 & 4,1 & $-0,8$ \\
Erdők & 8,2 & 9,6 & 1,4 \\
Egyéb természetközeli területek & 5,9 & 7,7 & 1,8 \\
Vizek és vizenyős területek & 2,8 & 2,6 & $-0,2$ \\
\hline
\end{tabular}

Forrás: CLC 1990 és 2018 alapján a szerzók számításai és szerkesztése 
3. ábra: A felszínborítás változásának térbeli mintázata 1990-2000, 2000-2006, 2006-2012,

2012-2018 között az 5×5 km-es referenciahálóra

Spatial pattern of land cover change between 1990-2000, 2000-2006, 2006-2012, 2012-2018 for $5 \times 5 \mathrm{~km}$ reference grids

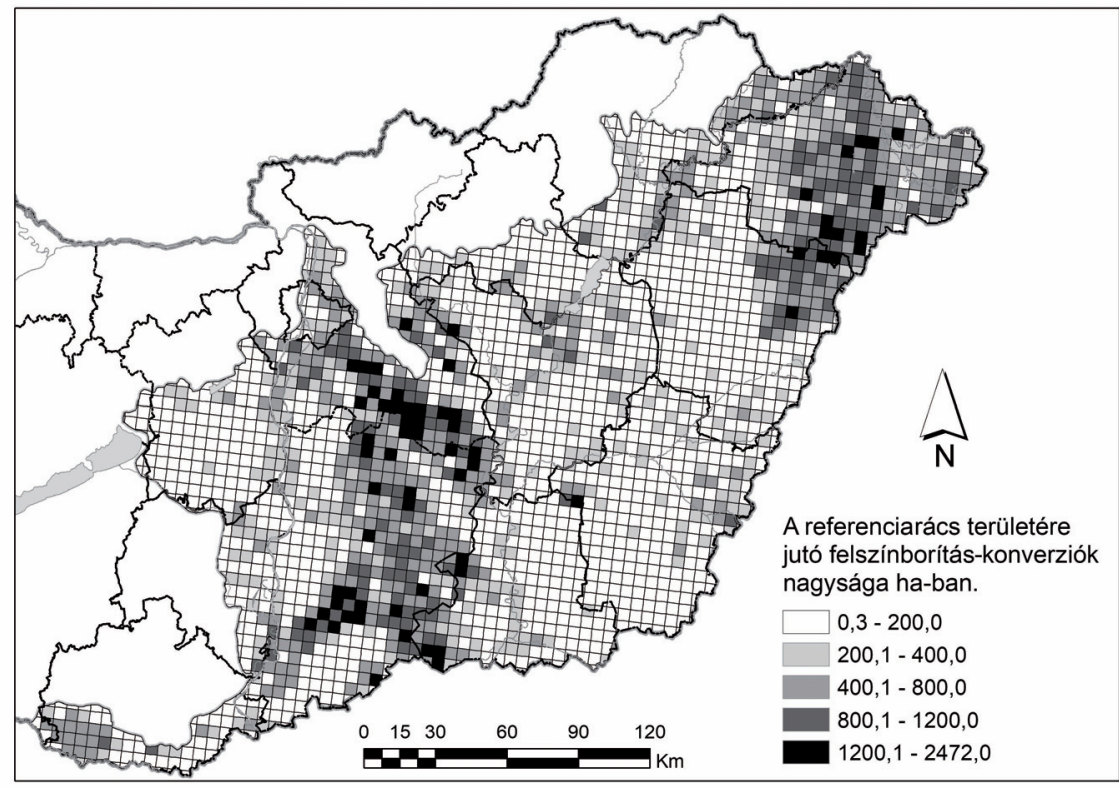

Forrás: CLC Change adatbázisok alapján a szerzők számitásai és szerkesztése

dolkodva hajlandóak voltak megváltoztatni területeik földhasználatát, melynek célja többnyire a megélhetés fenntartása, a bevételek lehetőség szerinti maximalizálása volt, még akkor is, ha ezek föként az agrártámogatásokból voltak realizálhatók. Vagyis a makrogazdasági körülmények és a szabályozási környezet változásai ebben az időszakban úgy hatottak a tájgazdálkodásra, hogy a földhasználók a környezeti szempontokat félretéve hozták meg döntéseiket, melyet számos interjúalanyunk véleménye is megerősít. Ennek a magatartásnak az okát a megkérdezettek is alapvetően az európai agrárpolitikai rendszerrel hozták összefüggésbe, melynek célkitűzései és preferált eszközei költségvetési ciklusonként változnak, ebből következően sok esetben egymásnak ellentmondó intézkedéséket is tartalmaznak.

A CLC Change részletes adatai alapján az Alföldön legjellemzőbb folyamat az agrárterületek erdő- és egyéb természetközeli területekké való átalakulása (elsősorban átmeneti erdős-cserjés területté, amelyek alapvetően az új erdőtelepítéseket jelzik a CLC-ben), amelyek az összes változás 15\%-át teszik ki (2. táblázat).

Az erdők területének növekedésével kapcsolatban a megkérdezett szakértők is több ízben kifejtették véleményüket. Az erdősítések által befolyásolt környezeti folyamatok és a jelenlegi erdőállomány minőségének megítélése régóta vita 
2. táblázat: A felszínborítás-kategóriák közötti legnagyobb területű konverziók az Alföldön Highest area conversions among the categories of land cover in the Great Hungarian Plain

\begin{tabular}{lcc}
\hline \multicolumn{1}{c}{ Kiindulás (mezg. ter.) } & Végállapot (erdöés termközeli) & Konverzió (ha) \\
\hline Nem öntözött szántóföld & Átmeneti erdős-cserjés területek & 62310 \\
Rét/legelö & Átmeneti erdős-cserjés területek & 15210 \\
Nem öntözött szántóföld & Lomblevelü erdők & 8279 \\
Szőlők & Átmeneti erdős-cserjés területek & 3146 \\
Komplex művelési szerkezet & Átmeneti erdős-cserjés területek & 2172 \\
\hline
\end{tabular}

Forrás: CLC Change adatbázisok adatai alapján a szerzők számításai és szerkesztése

tárgyát képezi. A mutatószámok és a vélemények alapján az erdősültség egyértelműen összefüggésbe hozható mind az európai uniós csatlakozás előtti, mind az azutáni időszak támogatási poltikájával. A kiváltó okok és hatások részletezése a cikknek nem feladata, az azonban kijelenhető, hogy az erdők aránya egyes térségekben tovább már nem növelhető, az őshonos fajok telepítése a klímaváltozás és a szárazodás miatt egyébként is nehézségekbe ütközik. Emellett társadalmi hatása is jelentős, hiszen a mezőgazdasági kultúrákhoz (pl. szőlő-gyümölcs, kertészet) képest kevésbé munkaintenzív, jövedelem csak hosszútávon realizálható belőle, így a vidéki területek munkaerőpiaci és szociális problémáinak megoldását inkább nehezíti, mint elősegíti.

Az Alföld nagytájának analízise mellett külön megvizsgáltuk az itt található 986000 ha nagyságú Natura 2000 ökológiai hálózatot érintő felszínborítási átalakulásokat is, melynek számszerű eredményeit az 3. táblázat foglalja össze.

A korábban már ismertetett általános trendek a Natura 2000 térségek esetében is érvényesülnek, azonban a védett jelleg, valamint a kezelési tervek által szabályozott keretek miatt több eltérést tapasztalhatunk. Ezeken az élőhelyeken

3. táblázat: A felszínborítás változása az alföldi Natura 2000 területeken Land cover changes in Natura 2000 areas of the Great Plain

\begin{tabular}{lccc}
\multicolumn{1}{c}{ Felszínboritás típusa } & $\begin{array}{c}\text { Területi arány, } 1990 \\
(\%)\end{array}$ & $\begin{array}{c}\text { Területi arány, } 2018 \\
(\%)\end{array}$ & $\begin{array}{c}\text { Változás } \\
(\%)\end{array}$ \\
\hline Települési területek & 0,3 & 0,4 & 0,1 \\
Szántóföldek & 35,3 & 32,5 & $-2,7$ \\
Szőlő & 0,2 & 0,1 & $-0,1$ \\
Gyümölcsös & 0,1 & 0,2 & 0,1 \\
Rét/legelö & 17,6 & 18,6 & 1,0 \\
Egyéb mezőgazdasági területek & 1,9 & 1,5 & $-0,4$ \\
Erdők & 13,9 & 14,7 & 0,7 \\
Egyéb természetközeli területek & 20,5 & 22,1 & 1,7 \\
Vizek és vizenyős területek & 10,3 & 9,9 & $-0,4$ \\
\hline
\end{tabular}

Forrás: CLC 1990 és 2018 adatai alapján a szerzók számitásai és szerkesztése 
a felszínborítás-változások nagysága 1990 és 2018 között 112.000 ha-t tett ki. A változások közül elsősorban a rét/legelö, valamint az egyéb természetközeli területek növekedését emelhetjük ki, melyet ez esetben egyúttal preferált konverziós irányoknak is tekinthetünk. A mezőgazdasági és egyéb természetközeli, valamint erdőterületek átalakulásának egyenlege 6500 ha volt az utóbbiak javára, melyben a meghatározó folyamat az átmeneti erdős-cserjés területek növekedése, és ezzel párhuzamosan a szántóföldek és rétek/legelők kiterjedésének csökkenése volt.

A Natura 2000 területek felszínborítás-változásának eredményei rámutatnak arra, hogy a vizsgált időszakban az alföldi tájak és védett élőhelyek állapotában jelentős minőségi változás nem történt. Ebben a tekintetben a természetvédelemi ágazat alapvetően a meglévő állapotok konzerválására volt képes.

\section{Következtetések, összegző javaslatok}

A primer adatgyüjtések és statisztikai elemzések segítségével áttekintett események alapján kijelenthető, hogy az alföldi térségekben lezajlott táji változásokban, tájtermelési folyamatokban a társadalom szemlélete és az eltérő területhasználati igények meghatározó szerepet töltenek be. A tapasztaltak szerint már a rendszerváltás előtt egy új típusú gondolkodásmód, azaz az új környezeti paradigma egyes elemei megjelentek, s ez a tájhasználatra ható szegmensekben, mind a gazdálkodásban, mind a természetvédelemben megnyilvánult. Ugyanakkor az is érzékelhető, hogy a környezettudatos elvek késve és nem kellő hatékonysággal épültek be a tájgazálkodással, földhasználattal, terület- és vidéktervezéssel összefüggő döntéshozatali mechanizmusokba és a fejlesztési gyakorlatokba. A tájtermeléshez kapcsolódó területhasználati konfliktusok és a történeti fordulópontokhoz (a rendszerváltás és az EU-csatlakozás) köthető szemléleti váltások, valamint azok hatásai a térinformatikai elemzés eredményeiben is visszaköszönnek, megerősítve az interjús vizsgálatunk eredményeit. Figyelemre méltó ugyanakkor, hogy lakossági kérdőívünk alapján az emberek közel harmada nem rendelkezik megfelelő információval, vagy nem tudja megítélni a természeti környezet állapotát, vagy annak változásait. Ez nemcsak a kérdezettek tájékozatlanságát, de a vidéki társadalom természettől való eltávolodását is jelzi, sőt utal arra, hogy a környezettudatos gondolkodás nemcsak a gazdálkodók esetében, de szélesebb körben sem jellemzöje az érintett települések lakosságának. Mindez az új környezeti paradigma kibontakozásának akadozására mutat rá.

Az áttekintett időszakban egyébiránt voltak pozitív hazai kezdeményezések - elsősorban stratégiák és fejlesztési koncepciók - amelyek kiemelt figyelmet fordítottak a kiskunsági és bácskai térségekre, azok településeire. Interjúalanyaink is alátámasztották, hogy a földhasználat ésszerű átalakítására vonatkozó elképzeléseket mind a szakirodalom, mind az országos dokumentumok részletesen taglalták (pl: Duna-Tisza közi Homokhátság fenntartható fejlesztése 2007; NÉS-2 
2017; Nemzeti Tájstratégia 2017). Az 1990-es évektől központi kormányhatározatok sora született a Duna-Tisza közi tájakon szükséges intézkedésekről: (2087/1995.(IV.3.); 2286/1996.(X.25.); 2271/1999.(X.22.); 2095/2004.(IV.27.). A 97/2005.(XII.25.) OGY határozat által elfogadott Országos Területfejlesztési Koncepció (OTK) bemutatta a térség integrált fejlesztésének prioritásait, a természeti degradációs folyamatok megállításának, az agrárszerkezet-váltásnak a fontosságát. Az OFTK a „Speciális táji, környezeti problémákkal, adottságokkal rendelkező vidéki térségek fejlesztési feladatai” (3.1.5.2) között több ízben is utal az általunk vizsgált térségek gondjaira és a megoldási alternatívákra. Mindezek mellett megjelentek a korábbi kutatásokra épülő új szellemű tervezés-előkészítést igénylő programok is, mint például a tájrehabilitációt és a helyi társadalmat átfogóan támogató tanyafejlesztési pályázatok. Érzékelhető az állam szerepvállalása és a tájakról való környezetorientált gondolkodás, ugyanakkor az irányításiintézményi rendszerekben megfigyelhető változtatások célja és eredményessége (legalábbis szakmai nézőpontok alapján) erősen vitatható. A primer adatgyüjtés során hallott szakirányú állásfoglalások egyaránt visszaigazolják, hogy az erőfeszítések nem hozták meg a kellő áttörést, és az antropogén tájhasználat, a helytelen földhasznosítás kedvezőtlen hatásai nem enyhültek. Az új paradigma tehát főként elvi szinten, „dokumentumok formájában van jelen”, a környezetorientált stratégiai elképzelések gyakorlati életben való rutinszerü megvalósítása egyelőre még várat magára. A régóta fennálló földhasználati konfliktusok, a természetvédelem és a gazdálkodás érdekellentétei, valamint az eltérő területhasznosítási igények azt mutatják, hogy a paradigmaváltásban mind döntéshozói, mind intézményi, mind lakossági szinteken elmaradás mutatkozik. Mindezt - a szakértői vélemények alapján - jelentősen befolyásolják az agrártámogatási gyakorlatok is, amelyek miatt a tájak használata és kezelése gyakran a pillanatnyi anyagi érdekek mentén történik.

Aggodalomra ad okot a természetvédelem „mozgásterének beszűkülése”, holott korábban ennek a szektornak alapvetően pozitív szerepe volt a tájhasználati változásokban. Ráadásul az interjúkban hallottak szerint, (legalábbis a mintaterületek vonatkozásában) mindezt tetézik az agrárágazat feszítő kérdései: a szakemberhiány, a modernizációs beruházások lelassulása, az agrártársadalom szétesése, polarizációja és a birtokkoncentrációval járó táji homogenizáció. A mezőgazdaság látszólagos pozícióelőnye meglehetősen ingatag. Meglátásunk egybevág az interjúalanyaink által elmondottakkal, vagyis a környezettudatos földhasználat kialakításában, ezekben az érzékeny tájakban a természetvédelmet nem lenne szabad alárendelni a gazdasági céloknak. Ugyanakkor a nemzeti parkoknak is el kell fogadniuk, hogy a gazdálkodás kiszorítása helyett annak ésszerüsítése és a kultúrtáji értékek megőrzése a cél. A természetvédelmi szakmának emellett nagy felelőssége van azon érdekek bemutatásában, amelyek a bürokratikus szabályozás helyett a táji problémák megértésére és az alföldi mozaikos adottságoknak megfelelő kezelésére hívják fel a figyelmet. 
Mindent figyelembe véve, úgy véljük, hogy a tájak igénybevételét a hosszú távú, komplex környezeti fenntarthatóság jegyében kell megtervezni, amelyben a gazdálkodás, a természet- és tájvédelem összehangolása mindinkább fontossá válik. A vizsgálatokra kijelölt térségekben az évtizedek óta zajló negatív folyamatok eljutottak arra a pontra, ahol mindenképpen újra kell gondolni a tájhasználat lehetőségeit. Valamennyi ágazatnak és a központi döntéshozatalnak arra kell törekednie, hogy a tájak kulturális evolúciójára ható társadalmi erők és eltérő érdekeltségek mentén feszülő törésvonalak megszünjenek. A kedvezőtlen táji és társadalmi folyamatok ugyanis csak akkor fordíthatók kedvező irányba, ha valamennyi szereplő - az állam, az agrár- és természetvédelmi szektor, valamint a települések és azok lakossága - között olyan, lokalitás-specifikus konszenzusok születnek, amelyek lehetővé teszik a kultúrtájak átgondolt használatát. Reményeink szerint a tanulmányunkban alkalmazott elméleti megközelítés és az ezt kiegészítő empirikus munka rávilágít a tájtermelés szereplőinek felelősségére, az új környezeti paradigma tájhasználatban is kifejeződő jelentőségére.

\section{Jegyzetek}

1 Vizsgálatainkat egyrészt „Az állam strukturális átalakulásaira adott intézményi és egyéni válaszok különböző földrajzi kontextusokban” című OTKA K109269 kutatáson belül (Az „Intézményi, társadalmiközösségi és egyéni válaszok az állam átstrukturálódására a tájgazdálkodás szemszögéből” c. altémában), másrészt az „Új környezeti paradigma megjelenése Közép Európában” című Bolyai János Kutatási Ösztöndíj keretében folytattuk.

2 A „New Environmental Paradigm” szóösszetételt elsőként két szociológus, Dunlap és Van Liere (1978) írták le azonos című módszertani tanulmányukban. A kezdetben attitűdök mérésére szolgáló metódus jelentésköre később kibővült, és mára a kifejezés a „növekedés határainak” felismeréséről, a termelés és a fogyasztás megfékezéséről szól. Egyszerre jelent „világnézetet” és egy olyan korszakot, amelyben a természet megóvása, a környezet védelme válik a legfőbb céllá (Kerényi 1995). A paradigma és a paradigmaváltás tudományelméleti koncepciója számos filozófiai, absztrakciós problémát is felvet, melynek kifejtése nem cikkünk feladata. Azonban azt meg kell jegyeznünk, hogy értelmezésünkben az ember-környezet relációt érintő paradigmaváltás túlmutat a Kuhn (1962) által leírt „paradigmaváltás=tudományos forradalom” megközelítésen. Paradigma alatt az adott kor szellemiségét tükröző gondolkodásoknak, vezérelveknek, értékeknek és cselekvési mintáknak, egy adott társadalom vagy egy közösség által elfogadott összességét értjük.

3 Fenntartható tájgazdálkodás alatt azt a széles körủ tájspecifikus tevékenységet értjük, amely biztosítja a társadalom számára szükséges környezeti javakat és megélhetést, ugyanakkor a fellelhető természeti és kultúrtáji értékek védelmét és hosszú távra szóló megőrzését.

4 Itt szeretnénk röviden utalni néhány alapvető fogalomra. Értelmezésünk szerint a földhasználat az adott felszín antropogén használati módja, amelynek meghatározása hosszabb idejű megfigyelést kíván, míg a felszínborítás egy adott időpontban, terepi vagy távérzékeléssel látható jellemző (vannak olyan felszínborítások, amelyek egyben jól tükrözik a földhasználatot is pl. szántóföldek esetében, de pl. a gyepeknél, erdőknél már nem ilyen egyértelmű a használati mód). A földhasználati módok adott tájban megnyilvánuló összetett rendszere maga a tájhasználat, mindezek tervezési alapú megközelítése pedig a tájhasználat-menedzsment.

5 Miután az OTKA kutatás több altémából állt, a kérdoívezés lefolytatásakor komplex szempontrendszert kellett figyelembe venni. A tájhasználati hasonlóságok miatt úgy véljük, hogy a mintaterületeinken kívül eső, Kisalföldön található Győrújfaluban kapott eredmények is fontos tanulsággal szolgálnak. 


\section{Köszönetnyilvánítás}

Kovács András Donát munkáját a Bolyai János Kutatási Ösztöndíj támogatta.

A tanulmány az Innovációs és Technológiai Minisztérium ÚNKP-19-4 kódszámú Új Nemzeti Kiválóság Programjának szakmai támogatásával készült.

A kézirat korábbi változatához többen is füztek megjegyzéseket, ezúton köszönjük Timár Judit, Nagy Erika és Csatári Bálint értékes segítségét.

\section{Irodalom}

Andrásfalvy B., Vargyas G. (szerk.) (2009): Antropogén ökológiai változások a Kárpát-medencében. PTE Néprajz-Kulturális Antropológia Tanszék, L'Harmattan, Budapest

Antrop, M. (1997): The concept of traditional landscapes as a base for landscape evaluation and planning; the example of Flanders. Landscape and Urban Planning, 1-2., 105-117. https:// doi.org/cf3xnk

Bíró M. (2011): Változástérképek használata tíz év alatt bekövetkezett élőhelypusztulási tendenciák kimutatására a Kiskunsági-homokhátság területén. Tájökológiai Lapok, 9., 357-374.

Boucher, Y., Grondin, P., Auger, I. (2014): Land use history (1840-2005) and physiography as determinants of southern boreal forests. Landscape Ecology, 3., 437-450. https://doi.org/f5thfx

Buckwell, A., Matthews, A., Baldock, D., Mathijs, E. (2017): CAP: Thinking Out of the Box. Further Modernisation of the CAP - Why, What and How? RISE Foundation, Brussels

Büttner Gy. (2010): Magyarország 1990-2000 és a 2000-2006 közötti felszínborítás változásainak összehasonlítása. In: Lóki J., Demeter G. (szerk.): Az elmélet és a gyakorlat találkozása a térinformatikában konferencia kiadványa. Universitas Alapítvány, Debrecen, 89-97.

Calvo-Iglesias, M. S., Fra-Paleo, U., Diaz-Varela, R. A. (2009): Changes in farming systems and population as drivers of land cover and landscape dynamics: the case of enclosed and semi-openfield systems in Northern Galicia (Spain). Landscape and Urban Planning, 3-4., 168-177. https://doi.org/bwp9sf

Cloke, P. J. (2000): Rural geography. In: Johnston, R. J., Gregory, D., Pratt, D., Watts, M. (eds.): Dictionary of Human Geography. 4th Edition. Blackwell Publishing, Oxford, 718-719.

Cosgrove, D. (1984): Social Formation and Symbolic Landscape. Croom Helm, Beckenham

Cosgrove, D. E. (1997): Cultural landscapes. In: Unwin, T. (ed.): Europe: A Modern Geography. Longman, London, 65-81.

Cosgrove, D. (2003): Landscape and the European sense of sight - eyeing nature. In: Anderson, K., Domosh, M., Pile, S. and Thrift, N. (eds.): Handbook of Cultural Geography. Sage, London, 249-268.

Csemez A., Salamin G. (2006): A táj esélye: vita a tervezésről, a fejlesztésről, a rendezésről. Falu Város Régió, 3., 2-12.

Csorba P. (2000): A tájökológiai szemlélet érvényesülése a tájvédelemben. In: Schweitzer F., Tiner T. (szerk.): Tájkutatási irányzatok Magyarországon. MTA FKI, Budapest, 25-35.

Csorba P. (2010): A földrajzi tájakhoz füződő identitástudat rétegei. Tájökológiai lapok, 1., 3-21.

Csorba P. (2011): Az Alföld tájváltozásainak tendenciái. In: Rakonczai J. (szerk.): Környezeti változások és az Alföld. Nagyalföld Alapitvány Kötetei 7. Nagyalföld Alapítvány, Békéscsaba, 149-158.

Csorba P., Csatári B. (2017): Tájföldrajz és táji önazonosság. Magyar Tudomány, 3., 284-292.

Dunlap, R. B., Van Liere, K. D. (1978): The new environmental paradigm. Journal of Environmental Psychology, 9., 10-19. https://doi.org/b2dx7g

Duray B., Keveiné Bárány I. (2010): Tájdinamikai vizsgálatok - Tájhasználat-változás, és regenerációs potenciál összefüggéseinek modellezése. In: Pál-Molnár E. (szerk.): Geoszférák 2009. A Szegedi Tudományegyetem Földtudományi Doktoriskolájának eredményei. SZTE Földrajzi és Földtani Tanszékcsoport, Szeged, 99-151.

EEA Report No 10/2017 Landscapes in Transition An Account of 25 Years of Land Cover Change in Europe. https:// www.eea.europa.eu/publications/landscapes-in-transition (Letöltés: 2018. november 04.) 
Ellis, E. C. (2011): Anthropogenic transformation of the terrestrial biosphere. Proceedings of the Royal Society A: Mathematical, Physical and Engineering Science, 1938., 1010-1035. https://doi.org/frg47d

Farkas J. Zs., Kovács A. D. (2017): Tájhasználatváltozás kiskunsági és bácskai példákon. In: Blanka V , Ladányi Zs (szerk.): Interdiszciplináris tájkutatás a XXI. században: a VII. Magyar Tájökológiai Konferencia tanulmányai. Szegedi Tudományegyetem Földrajzi és Földtudományi Intézet, Szeged, 146-153.

Fazio, S., Modica, G. (2018): Historic rural landscapes: Sustainable planning strategies and action criteria. The Italian experience in the global and European context. Sustainability, 10., 1-27. https://doi.org/gfr2m8

Foley, J.A., DeFries, R., Asner, G.P., Barford, C., Bonan, G., Carpenter, S.R., Chapin, F.S., Coe, MT. Daily, G.C., Gibbs, H.K., Helkowski, J.H., Holloway, T., Howard, E.A, Kucharik, C.J., Monfreda, C., Patz, J.A., Prentice, I.C., Ramankutty, N., Snyder, P.K. (2005): Global consequences of land use. Science, 309., 570-574. https://doi.org/dqd2tm

Frisnyák S. (2001): A kultúrtáj kialakulása az Alföldön. In: Dormány G. et. al. (szerk.): A földrajz eredményei az új évezred küszöbén. SZTE TTK Természeti Földrajzi Tanszék, Szeged, 213-223.

Gailing, L., Leibenath, M. (2015): The social construction of landscapes: Two theoretical lenses and their empirical applications. Landscape Research, 2., 123-138. https://doi.org/c8td

Gailing, L. (2012): Dimensions of the social construction of landscapes: Perspectives of new institutionalism. Proceedings of the Latvian Academy of Sciences: A, Human and Social Sciences, 66., 195-205.

Greider, T., Garkovich, L. (1994): Landscapes: The social construction of nature and the environment. Rural Sociology, 1., 1-24. https://doi.org/bpwvd6

Giddens, A. (1984): The Constitution of Society: Outline of the Theory of Structuration. University of California Press, Berkeley

Görg, C. (2007): Landscape governance. The "politics of scale"and the "natural“ conditions of places. Geoforum, 5., 954-966. https://doi.org/dk38j9

Halfacree, K (2006): Rural space: Constructing a three-fold architecture. In: Cloke, P., Marsden, T. Mooney, P. (eds.): The Handbook of Rural Studies. Sage, London, 44-62. https://doi.org/c6zz

Hillier, B., Hanson, J. (1984): The Social Logic of Space. 5th edition. University Press, Cambridge

Kauffman, S., Levin, S. (1987): Towards a general theory of adaptive walks on rugged landscapes. Journal of Theoretical Biology, 1., 11-45. https://doi.org/10.1016/S0022-5193(87)80029-2

Kerényi A. (1995): Általános környezetvédelem - Globális gondok, lehetséges megoldások. Mozaik Kiadó, Szeged

Kerényi A. (2006): Kényelmetlen, de alapvető: A táj eltérő értelmezései és azok tervezési-védelmi jelentősége. Falu Város Régió, 3., 18-22.

Kerényi A. (2007): Tájvédelem. Pedellus Novitas Kft., Debrecen

Konkoly-Gyuró, É., Király, G., Dezső, N., Balázs, P., Tirászi, Á. (2017): Overview of the 18th-20th century military surveys in the light of the land cover change assessment in Eastern Central Europe. E-PERIMETRON, 4., 142-180. https://doi.org/cfx8dg

Kovács, A. D., Farkas, J. Zs., Hoyk, E. (2017): Homokhátság - a special rural area affected by aridification in the Carpathian basin, Hungary. European Countryside, 1., 29-50. https://doi.org/dcpg

Kovács F. (2011): Az alföldi területhasználat és változásainak értékelése. In: Rakonczai J. (szerk.): Környezeti változások és az Alföld. Nagyalföld Alapitvány Kötetei. Nagyalföld Alapítvány, Békéscsaba, 149-159.

Kőszegi, M., Bottlik, Zs., Telbisz, T., Mari, L. (2015): Human-environment relationships in modern and postmodern geography. Hungarian Geographical Bulletin, 2., 87-99. https://doi.org/dcph

Kuhn, T. (1984). A tudományos forradalmak szerkezete. Gondolat Kiadó, Budapest

Kulcsár, L. (eds.) (2014): Social and Economic Impact of Climate Change in Rural Hungary. University of West Hungary Faculty of Economics Sopron, Sopron

Lefebvre, H. (1991): The Production of Space. Blackwell, Oxford, Cambridge

Marosi S. (1981): Tájkutatási irányzatok, tájértékelés, tájtipológiai eredmények. MTA FKI, Budapest

Marsden, T. (1998): New rural territories: Regulating the differentiated rural space. Journal of Rural Studies, 1., 107-117. https://doi.org/cf2j4z 
Massey, D. (1991): A global sense of place. Marxism Today, 38., 24-29.

Minca, C. (2013): The cultural geographies of landscape. Hungarian Geographical Bulletin, 1., 47-62.

Muir, R. (1998): Reading the landscape, rejecting the present. Landscape Research, 1., 71-82. https:// doi.org/d94bkm

Newby, H. (1985): 25 years of rural sociology. Sociologia Ruralis, 3-4., 207-213. https://doi.org/ $10.1111 / \mathrm{j} .1467-9523.1985 . t b 00762 . x$

OFTK Országos Fejlesztési és Területfejlesztési Koncepció. (2014): Készült a területfejlesztési politika megújításáról, az új Országos Területfejlesztési és az új Országos Fejlesztési Koncepció kidolgozásáról szóló 1254/2012. (VII. 19.) Korm. határozat alapján. https://regionalispolitika.kormany.hu/download/a/c9/e0000/MK14001.pdf Letöltés: 2018. december 05.

OTK Országos Területfejlesztési Koncepció. (2005): Országos Területfejlesztési Hivatal, Készült a VÁTI Kht. - Stratégiai Tervezési Igazgatóság közreműködésével. https://www.palyazat.gov.hu/doc/ 207\# (Letöltés: 2018. december 05.)

Plieninger, T., Höchtl, F., Spek, T. (2006): Traditional land-use and nature conservation in European rural landscapes. Environmental Science \& Policy, 9., 317-321. https://doi.org/cjg7jn

Renes, H. (2015): Historic landscapes without history? A reconsideration of the concept of traditional landscapes. Rural Landscapes: Society, Environment, History, 1. p.Art. 2. https://doi.org/c8tr

Rössler, M. (2006): World Heritage cultural landscapes: A UNESCO flagship programme 1992-2006. Landscape Research, 4., 333-353. https://doi.org/d96f89

Sargolini, M. (2013): Urban Landscapes: Environmental Networks and the Quality of Life. Springer Verlag https://doi.org/c8tf

Soja, E. (1989): Postmodern Geographies, The Reassertion of Space in Critical Social Theory. Verso Press, London

Solymosi K. (2011): Indicators for the identification of cultural landscape hotspots in Europe. Landscape Research, 1., 3-18. https://doi.org/chv6c8

Swanwick, C. (2009): Society's attitudes to land and landscape. Land Use Policy, 1., 62-75. https:// doi.org/fwh6nh

Szilassi P. (2015): Felszínborítás és tájmintázat változása, mint az antropogén környezetváltozások indikátora In: Rakonczai J., Blanka V., Ladányi Zs. (szerk.): Tovább egy zöldebb úton: A Szegedi Tudományegyetem Földrajzi és Földtani Tanszékcsoport részvétele a ZENFE programban (2013-2015). SZTE TTIK Földrajzi és Földtani Tanszékcsoport, Szeged, 154-163.

Szilassi P. (2017): Magyarországi kistájak felszínborítás változékonysága és felszínborítás mozaikosságuk változása. Tájökológia Lapok, 2., 131-138.

Taylor, K., Lennon, J. (2011): Cultural landscapes: A bridge between culture and nature? International Journal of Heritage Studies, 6., 537-554. https://doi.org/b9jtqh

Thrift, N. (1999): Steps to an ecology of place. In: Allen, J., Massey, D. (eds.): Human Geography Today. Polity Press, Cambridge, 295-321.

Yu, Q., Verburg, P.H., Wu, W. (2018): Environmental cognitions mediate the causal explanation of land change. Journal of Land Use Science, 5., 535-548. https://doi.org/c8tc

Wang, X., Liu, W., Chen, J. (2013): Theoretical evolution of modern land use planning. Progress in Geography, 10., 1490-1500. https://doi.org/dcpj

Widgren, M. (2012): Resilience thinking versus political ecology; understanding the dynamics of small-scale, labour-intensive farming landscapes. In: Plieninger, T., Bieling, C. (eds.): Resilience and the cultural landscape. Cambridge, 95-110. https://doi.org/f23mts

Whatmore, S. (1993): On doing rural research (or breaking the boundaries). Environment and Planning A, 5., 605-607.

Wöbse, H. H. (2002): Landschaftsästhetik. Ulmer Verlag, Stuttgart

Wylie, J.W. (2007): Landscape. Routledge, London 